\title{
ABUNDANCE OF TREES USED AS FOOD BY PRIMATES IN FRAGMENTS OF ATLANTIC FOREST
}

\author{
Valdecir da SILVA ${ }^{\mathbf{1}}$; Vera Lúcia da SILVA ${ }^{2}$; Válter da SILVA ${ }^{\mathbf{3}}$; Dimítri de Araújo COSTA \\ Francisco de Assis da SILVA; ${ }^{5}$ Geuba Maria Bernardo da SILVA ${ }^{6}$; Martin Lindsey \\ CHRISTOFFERSEN ${ }^{7}$
}

\begin{abstract}
${ }^{1}$ Bacharel em Ecologia/Universidade Federal da Paraíba (UFPB); Especialista em Educação em Direitos Humanos/UFPB; Especialista em Biologia Vegetal/Instituto Superior de Educação Ibituruna (ISEIB); Licenciado em Ciências Biológicas/Cruzeiro do Sul, Brasil. E-mail: valdecir.silvas@gmail.com

${ }^{2}$ Licenciada em Ciências Biológicas/Universidade Estadual Vale do Acaraú (UVA-CE); Especialista em Saúde da Família/UFPB; Especialista em Educação em Direitos Humanos/UFPB; Bacharela em Secretariado Executivo Bilíngue/UFPB, Brasil. E-mail: vlucia65@gmail.com

${ }^{3}$ Bacharel em Engenharia Agronômica/UFPB; Especialista em Engenharia de Segurança do Trabalho/Instituto de Educação Superior da Paraíba (IESP); Mestre em Agroecologia/UFPB, Brasil. E-mail: valtermataraca@gmail.com

${ }^{4}$ Bacharel e Licenciado em Ciências Biológicas/UFPB; Mestre em Ecologia e Monitoramento Ambiental/UFPB; Doutorando em Desenvolvimento e Meio Ambiente (PRODEMA)/UFPB, Brasil. E-mail: costa.researcher@yahoo.com.br

${ }^{5}$ Bacharel em Ecologia/UFPB; Mestre em Desenvolvimento e Meio Ambiente (PRODEMA)/UFPB, Brasil. Email: assismandela@gmail.com

${ }^{6}$ Bacharela em Ecologia/UFPB, Brasil. E-mail: geubasilva@gmail.com

${ }^{7}$ Bacharel e Licenciado em Ciências Biológicas/Universidade de São Paulo (USP); Doutor em Ciências Biológicas/USP; Professor Titular/UFPB, Brasil. E-mail: mlchrist@dse.ufpb.br
\end{abstract}

\begin{abstract}
Forest fragmentation favours the propagation of some arboreal primate species that can alter the floristic composition of a community. This process may be associated with the loss of seed dispersants. In this work we propose to identify if the presence of frugivorous primates of medium and large size (Sapajus flavius and Alouatta belzebul) can influence forest diversity and structure. Further, we ask if the size of the fragment affects the availability of resources for these primates. Three fragments were studied in the Atlantic Forest of the State of Paraíba, Brazil, located in the municipalities of Sapé, Mamanguape, Rio Tinto, and Mataraca. In each area 25 plots of 50 x 4 m were delimited, randomly distributed along trails and transects. All trees with chest-high circumferences (CAP) above $12 \mathrm{~cm}$ found within the plots were marked with ribbons, and numbered continuously. A total of 114 plant species were documented in the Pacatuba Forest, 79 in the Asplan Forest, and 97 in the "Guaribas" (Sema III) Biological Reserve (REBIO) Forest. According to the Chao and Jacknife estimators, the REBIO Guaribas Forest can present more species than recorded in the present
\end{abstract}


investigation. Species Tapirira guianensis, Protium giganteum and Protium heptaphyllum are the most abundant in the Asplan, Pacatuba and Sema III Forests, respectively. In the REBIO Guaribas Forest, the Shannon diversity index was $\left(\mathrm{H}^{\prime}\right)=3.75$, the Alpha-Fisher index was $=26.57$ and the Simpson index $(1-\mathrm{D})$ was $=0.90$. Pacatuba was the forest fragment with the highest index of diversity $\left(\mathrm{H}^{\prime}\right)=$ 375 , Alpha-Fischer $=33.74$ and Simpson $(1-D)=0.95$. Pacatuba and REBIO Guaribas Forsts possess greater Beta diversity. The results suggest that local and historical factors possibly increase Beta diversity, contributing to the increase in resources used as food by primates. Therefore, the presence of primates of medium and large size in the Pacatuba Forest may affect the diversity of resources, contributing to the dispersion of large fruits and seeds. The presence of primates of medium and large size can thus contribute to the preservation of floristic diversity in forest fragments.

Key words: Forest fragmentation; Availability of resources; Diversity.

\section{ABUNDÂNCIA DE ÁRVORES USADAS COMO RECURSO POR PRIMATAS EM FRAGMENTOS DE MATA ATLÂNTICA}

Resumo. A fragmentação florestal favorece a propagação de algumas espécies arborícolas, que podem alterar a composição florística da comunidade, podendo estar associados à perda de dispersores de sementes. Neste trabalho, foi verificado se a presença de primatas frugívoros de médio e grande porte (Sapajus flavius e Alouatta belzebul) podem influir na diversidade e estrutura florestal; bem como se o tamanho do fragmento afeta a disponibilidade de recursos para estes primatas. Foram estudados três fragmentos na Mata Atlântica do Estado da Paraíba, localizadas nos municípios de Sapé, Mamanguape, Rio Tinto e Mataraca. Em cada área, foram delimitados 25 "plots", medindo 50 x 4 m, localizados ao longo de trilhas e transectos, distribuídos de forma aleatória. Todas as árvores encontradas dentro dos "plots", com circunferência à altura do peito (CAP) $\geq 12 \mathrm{~cm}$, foram marcadas com fitas, e numeradas de forma contínua. Foram registradas 114 espécies vegetais na mata de Pacatuba, 79 na mata da Asplan, e 97 na mata da Reserva Biológica (REBIO) "Guaribas" (Sema III). De acordo com os estimadores $\mathrm{Chao}_{1}$ e Jacknife ${ }_{1}$, a mata REBIO Guaribas pode apresentar mais espécies em relação ao que foi registrado na presente pesquisa. As espécies Tapirira guianensis, Protium giganteum e Protium heptaphyllum são as mais abundantes na mata da Asplan, Pacatuba e Sema III, respectivamente. Na mata REBIO Guaribas, o índice de diversidade de Shannon (H') foi 3.2, Alpha-Fisher $=26.57$ e Simpson $(1-D)=0.90$. Pacatuba foi o fragmento de mata com maior índice de diversidade $\left(\mathrm{H}^{\prime}\right)=3.75$, Alpha-Fisher $=33.74$ e Simpson $(1-\mathrm{D})=0.95$. Pacatuba e REBIO Guaribas possuem maior diversidade Beta. Os resultados sugerem que possivelmente fatores locais e históricos aumentam a diversidade Beta, podendo contribuir para o aumento dos recursos usados como alimento pelos primatas. Além disso, a presença de primatas de médio e grande porte na mata Pacatuba pode afetar a diversidade de recursos, ao contribuir com a dispersão de frutos e sementes de tamanho 
grande. A presença de primatas de médio e grande porte pode contribuir para a conservação e manutenção da diversidade florística em fragmentos.

Palavras-chave: Fragmentação florestal; Disponibilidade de recursos; Diversidade.

\section{ABUNDANCIA DE ÁRBOLES USADOS COMO RECURSO POR PRIMATES EN FRAGMENTOS DE FLORESTA ATLÁNTICA}

Resumen. La fragmentación forestal favorece la propagación de algunas especies arborícolas que pueden alterar la composición florística de la comunidad, pudiendo estar asociado a la pérdida de dispersores de semillas. En este trabajo fue verificado si la presencia de primates frugívoros de mediano y grande porte (Sapajus flavius y Alouatta belzebul) pueden influir en la diversidad y estructura forestal; como también, si el tamaño del fragmento afecta la disponibilidad de recursos para estos primates. Fueron estudiados tres fragmentos en la Floresta Atlántica del estado de Paraíba-Brasil, localizados en los municipios de Sapé, Mamanguape, Rio Tinto y Mataraca. En cada área, fueron delimitados 25 "plots" midiendo 50 x 4 m, localizados a lo largo de senderos y transectos, distribuidos de forma aleatoria. Todos los árboles encontrados dentro de los "plots", con circunferencia a la altura del pecho $(\mathrm{CAP}) \geq 12 \mathrm{~cm}$, fueron marcadas con cintas, y numeradas de forma continua. Fueron registradas 114 especies vegetales en la floresta de Asplan y 97 en la Reserva Biológica (REBIO) "Guaribas" (Sema III). De acuerdo con los estimadores Chao ${ }_{1}$ y Jacknife ${ }_{1}$, la floresta REBIO Guaribas puede presentar más especies en relación a lo que fue registrado en la presente investigación. Las especies Tapirira guianensis, Protium giganteum y Protium heptaphyllum son las más abundantes en la floresta de Asplan, Pacatuba y Sema III, respectivamente. En la floresta REBIO Guaribas, el índice de diversidad de Shannon $\left(H^{\prime}\right)=3.75$, Alpha-Fisher $=26.57$ y Simpson $(1-D)=0.90$. Pacatuba fue el fragmento de floresta con mayor índice de diversidad $\left(\mathrm{H}^{\prime}\right)=375$, Alpha-Fisher $=33.74$ y Simpson $(1-$ D) $=0.95$. Pacatuba y REBIO Guaribas poseen mayor diversidad Beta. Los resultados sugieren que posiblemente factores locales e históricos aumentan la diversidad Beta, pudiendo contribuir para el aumento de los recursos usados como alimento por los primates. Además de eso, la presencia de primates de mediano y grande porte en la floresta Pacatuba, puede afectar la diversidad de recursos, al contribuir con la dispersión de frutos y semillas de gran tamaño. La presencia de primates de mediano y grande porte puede contribuir para la conservación y mantenimiento de la diversidad florística en fragmentos.

Palabras clave: Fragmentación forestal; Disponibilidad de recursos; Diversidad.

\section{INTRODUCTION}

The rate of destruction of tropical forests is presently alarming (PUIG, 2008). Tha Atlantic Forest in particular has been drastically reduced and fragmented due to excessive exploration, deforestation and fires, being presently restricted to less than $7 \%$ of its original area 
(CHIARELLO, 1994; DALPONTE, LIMA, 1999). The destruction of tropical forests and their deforestation reduce forested areas, transforming them into fragments known as patches or islands. Such a process of reduction and isolation of the natural vegetation affects the structure and functioning of plant communities, resulting in loss of biological biodiversity, death of trees in bordering areas, among other changes (CERQUEIRA et al., 2003). Fragmentation causes isolation among the surviving forested áreas. According to Laurance and Vasconcelos (2009), the distance between two forest fragments or the distance existing between a fragment and a continuous area of forest may affect the displacement of animals and of plant propagules. Deforestated areas measuring from 15 to $100 \mathrm{~m}$ in width may act as barriers for the displacements of several species, including arboreal mammals (GILBERT; SETZ, 2001; LAURANCE; VASCONCELOS, 2009).

In Northeastern Brazil, Bonvicino (1989) observed that some species of trees provided more than one food item. For example, the species Guapira sp furnishes leaves, flowers and fruits as food items. In that research, 47 species of plants were used as food by the guaribamonkeys. Thirty-six percent of these plants were consumed by Callithrix jacchus (the Whitetuft Marmoset) and 12,7\% were consumed by some species of bats. Camargo et al. (2008) observed a reduction in the consumption of fruits during the dry season and an increase in the consumption of the other food items such as leaves and flowers, due to the reduction of the availability of fruit during the periods of lower precipitation. Tabarelli et al. (2010) reinforced that the borders resulting from fragmentation stimulate the proliferation of pioneer species and a constant reduction in the abundance of species with lower growth rates. This occurrs because most of these species have large seeds and their dispersal agents, the frugivorous animals, are unable to become established in their original habitat and thus search for other more favourable areas. This breaks existing links previously existing with the plants that depend on animals for dispersal. The pioneer species, which do not necessarily depend on animals for dispersal, tend to dominate, because their seeds are small and may be transported by physical agents such as water and wind. They gradually replace species which are late to arrive. This affects the whole community in the long run. Even strongly resilient forests, when fragmented, reduce their availability of resources, demanding many years to recover and to furnish the same resources which were available previously (GUREVITCH; SCHEINER; FOX, 2009).

Primates are important agents for the regeneration of fragmented forests, because they are effective dispersants of large seeds (IZAR, 2008; MOURA; McCONKEY, 2007). Thus, forest fragments that possess large primates are possibly more diverse in trees used as food 
resources. This hypothesis is based on three premises: i) The size of the primate affects the species composition of plants in the forest, because when a primate chooses between fruit of small seeds or of large seeds belonging to different species, it is in fact selecting the species which it will disperse; ii) The size of the primate affects the composition and distribution of species because the selected fruit are ingested and dispersed during their daily locomotion; iii) The size of the primate affects the composition, the distribution of species, and consequently the forest structure. Depending on the type of seed dispersed, the fragment will have emergent species or species tolerant of shade. In this paper we evaluate if (1) the size of a forest fragment indeed affects the availability of resources for non-human primates in the Atlantic Forest in the State of Paraíba and if (2) the presence of frugivorous primates of median and large size (Sapajus flavius and Alouatta belzebul) influence the diversity and structure of the forest.

\section{MATERIAL AND METHODS}

\section{Study area}

Three forest fragments were studied, two located in the northern coast of the State of Paraíba, and the third located about $50 \mathrm{~km}$ inland (Fig. 1). The forest of Pacatuba Farm is a Private Reserve of the Natural Heritage (RPPN) with 266.53 ha, located in the Municipality of Sapé. The forst of ASPLAN (Sugar Cane Planters Association of Paraíba), with 96.5 ha, is a Legal Reserve located between the Municipalities of Mamanguape and Mataraca. The Biological Reserve (REBIO) "Guaribas" SEMA III (327.0 ha), also known as "Mata do Maracujá", is located in the Municipality of Rio Tinto. The three areas share an $A S$-type climate, that is, a humid tropical climate, with rains in the fall-winter (KÖPPEN, 1948). The rainy season begins during the month of March, at the beginning of Fall, and continues until July, just after the onset of Winter. Between 2008 and 2011, the maximum rainfall in Asplan and Sema III occurred in the month of April, with $279.6 \mathrm{~mm}$ and $282.5 \mathrm{~mm}$, respectively. Lowest precipitation occured in November, with $18.9 \mathrm{~mm}$ and $11.0 \mathrm{~mm}$, respectively. In Pacatuba, maximum precipitation $(236.2 \mathrm{~mm})$ occurred in the month of July and minimum rainfall, 7.4 mm, occurred in October (Fig. 2).

In each area 25 plots measuring $50 \times 4$ meters were delimited. These plots were located along trails and transects within the forest fragments (Fig. 3). Some of these trails measured up to $2 \mathrm{~km}$ long. Along the longest trails, points were established by draws to determine the beginning of each vegetation plot. The side in which a plot was positioned was selected at ramdom with the through of a coin. Plots were rectangular, a shape that may 
contain more species than a square or circular plot of the same size (GUREVITCH; SCHEINER; FOX, 2009), and may thus better sample the vegetation. These plots were delimited by string. All trees located within each plot, with a circumference at the height of the chest $(\mathrm{CAP}) \geq 12 \mathrm{~cm}$ were marked with a ribbon and numbered consecutively. Later, the values of CAP were transformed into diameters at chest height (DAP), using the formula $\mathrm{DAP}=\mathrm{CAP} / \pi$, where $(\pi=3.14)$. The height of all marked trees were estimated visually using a scaled stick of 6 meters. Each study area that contained at least $5 \%$ of the total number of individuals was considered abundant.

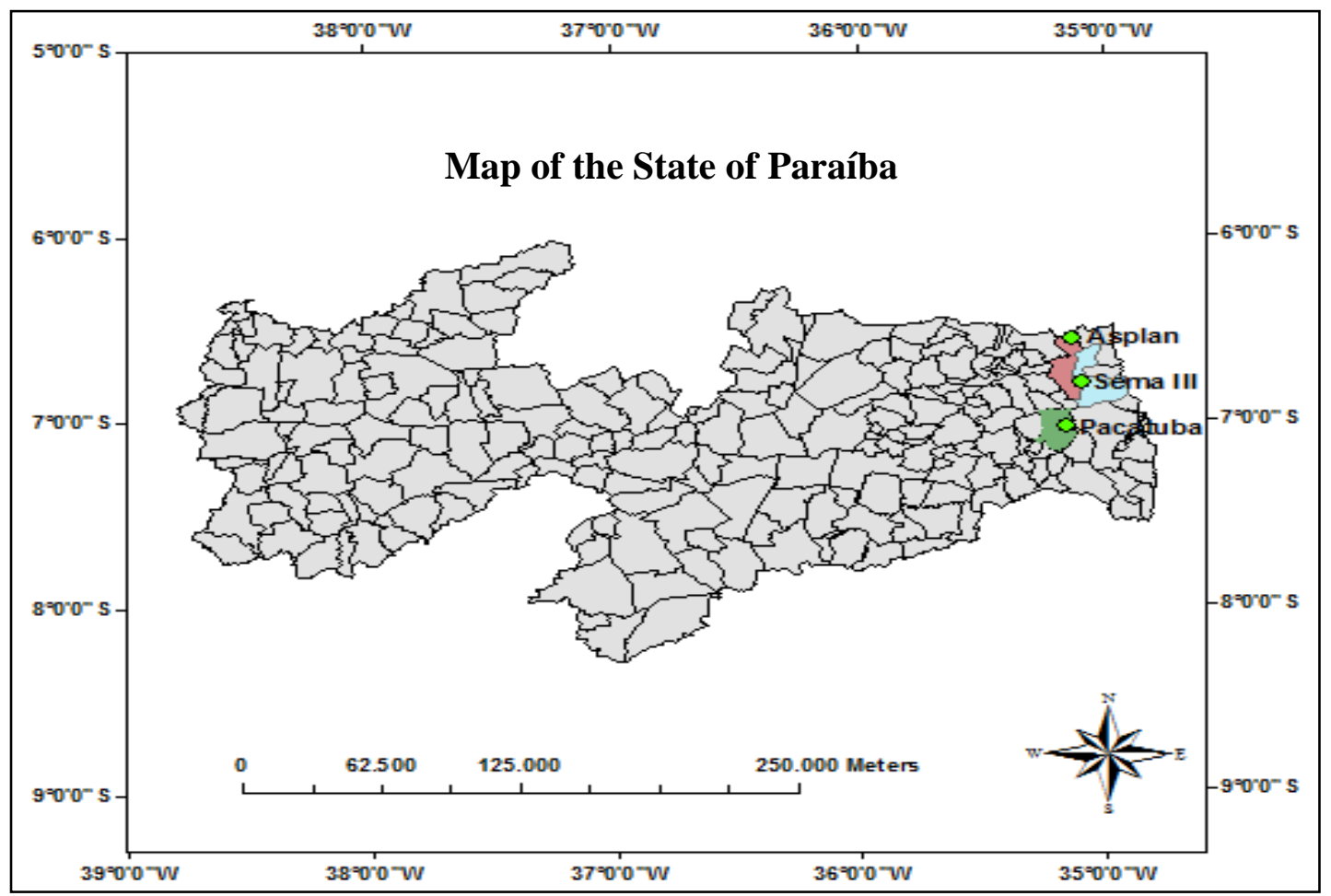

Figure 1. Location of study areas, in the State of Paraíba, Northeastern Brazil. Source: National Water Agency.

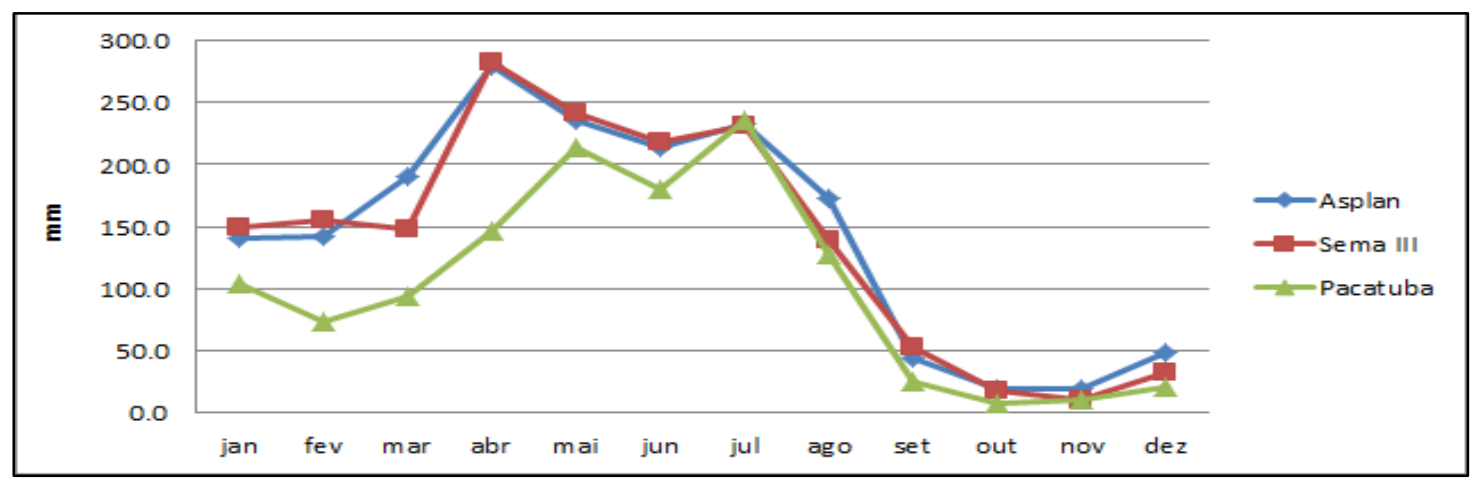


Figure 2. Pluviometric mean of the study areas (2008-2011). Source: AESA/PB (Agência Executiva de Gestão das Águas do Estado da Paraíba).

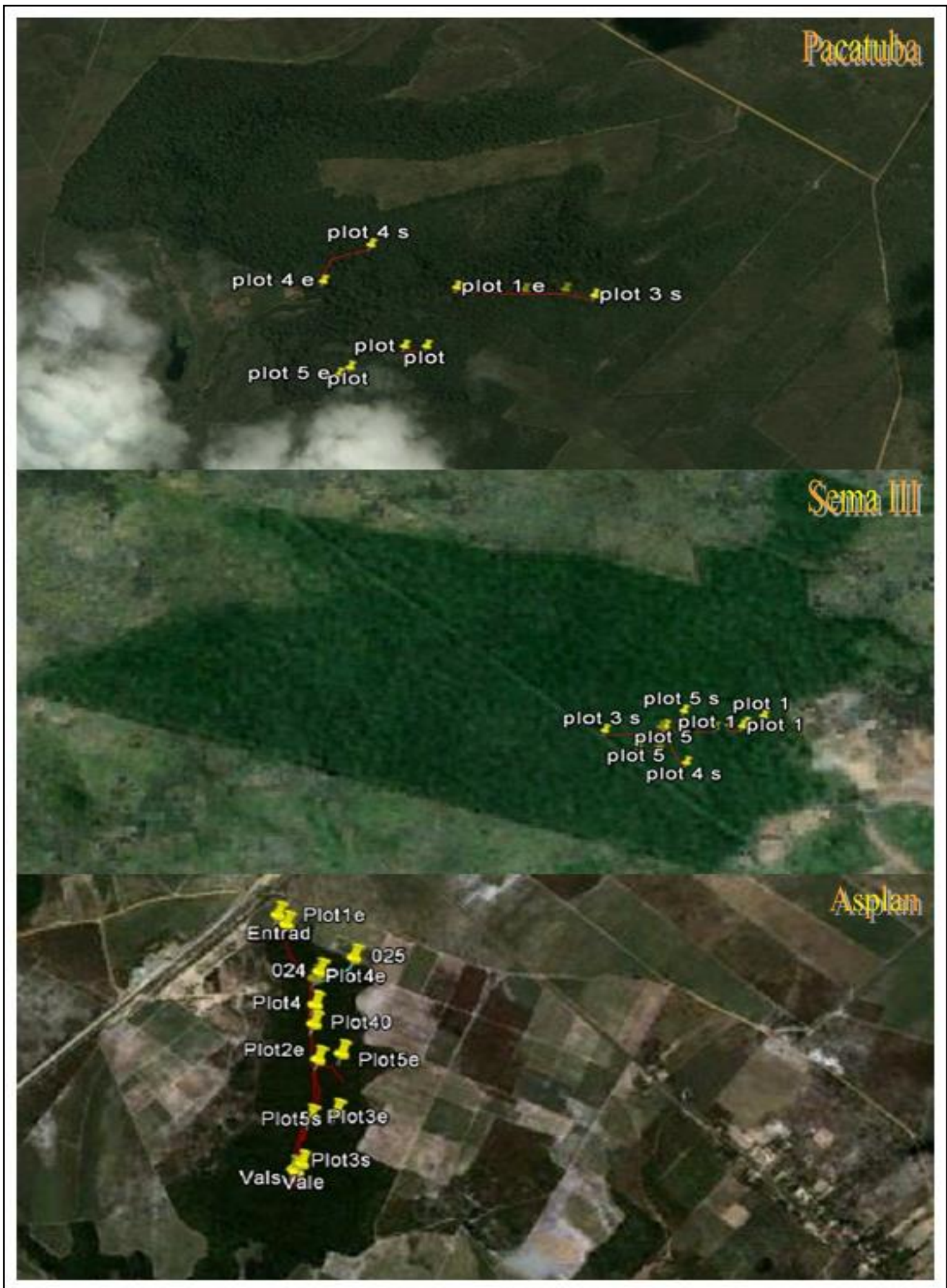

Figure. 3. Distribution of plots in the study areas. Source: Google Earth (2018).

The REBIO Guaribas (SEMA III) Forest is located about one km away from an urban area. Altitudes vary from 20 to $134 \mathrm{~m}$ above sea level (GOOGLE EARTH, 2018), having a 
brook flowing through it. The Pacatuba Farm Forest has altitudes that vary from $75 \mathrm{~m}$ to 150 $\mathrm{m}$, being drained by several permanent streams (DE SOUZA, 2005). In the localities with more water available the forest is larger and the vegetations is denser. At higher altitudes the soil varies from sand to clay, with a vegetation of the Savanna type, trees being of small to median size. The ASPLAN Forest is unike in not having water streams. Its relief is not very steep, altitudes varying from 96 to 136 m (GOOGLE EARTH, 2018). All three fragments are surrounded by sugar-cane plantations or pastures. The REBIO Guaribas Forest is further surrounded by an urban area.

Some plant species were identified in situ. For the identification of the remaining species, samples of the vegetative structures (leaves) and, when possible, of the reproductive structures (flowers and fruits) were obtained. Exicatae were prepared from the collected samples and compared to those deposited in the Herbarium Lauro Pires Xavier (JPB) of the Federal University of Paraíba (UFPB/Campus I), in order to confirm identifications. The new exicatae were deposited in this herbarium.

\section{Data analyses}

The data were inserted into electronic spredsheets for preliminary analyses. They were later analysed in different programs. The statistic program "Past" (version 3.13) was used to evaluate the alfa diversity of the communities. Indices of Shannon-Wiener (H'), Simpson (1D) and Alpha-Fisher were used.

Two non-parametric estimators were used $\left(\mathrm{Chao}_{1}\right.$ and Jaccknife $\left.{ }_{1}\right)$, calculated with the program "Estimates" (version 7.52).

Beta diversity, corresponding to the dissimilarity between species of two or more communities (BARROS, 2007), represents the dissimilarity between species of two or more communities. Beta diversity was estimated for the three studied areas. As lowest similarities indicate highest dissimilarities; the Beta diversity ndicates few shared species.

The "Jaccard" similarity index was used in the three study areas. The advantage of this index is that it is not influenced by the more abundant species. Furthermore, areas with a history of environmental perturbations are more susceptible to the appearance of pioneer species, and the abundance of these species would also be able to influence the similarity.

\section{RESULTS AND DISCUSSION}

A total of 1339 trees were recorded in the Asplan Forest, belonging to 79 species. In the Pacatuba Forest we recorded 956 trees, while in REBIO Guaribas (Sema III) Forest 
(alternatively named the Psiion-Fruit Forest), a total of 996 individuals belonging to 97 species were recorded. The Asplan Forest has the highest abundance of trees with a height of uto to $10 \mathrm{~m}$; trees with Heights up to $50 \mathrm{~m}$ were only found in Pacatuba Farm Forest. At REBIO Guaribas Forst, the maximum height of the trees reached $35 \mathrm{~m}$ (Fig. 4A). Regarding tee diameter, Pacatuba Forest differs from the remaining ones for having trees with a large diameter, such as of an individual of Parkia pendula that has $171.02 \mathrm{~cm}$; in REBIO Guaribas and Asplan, the largest diameters did not overreach $82.74 \mathrm{~cm}$ (Fig. 4B). REBIO Guaribas further presented the largest number of trees with up to $15 \mathrm{~cm}$ in diameter. The mean diameter in Pacatuba is higher than for the remaining areas (Tab. 1).

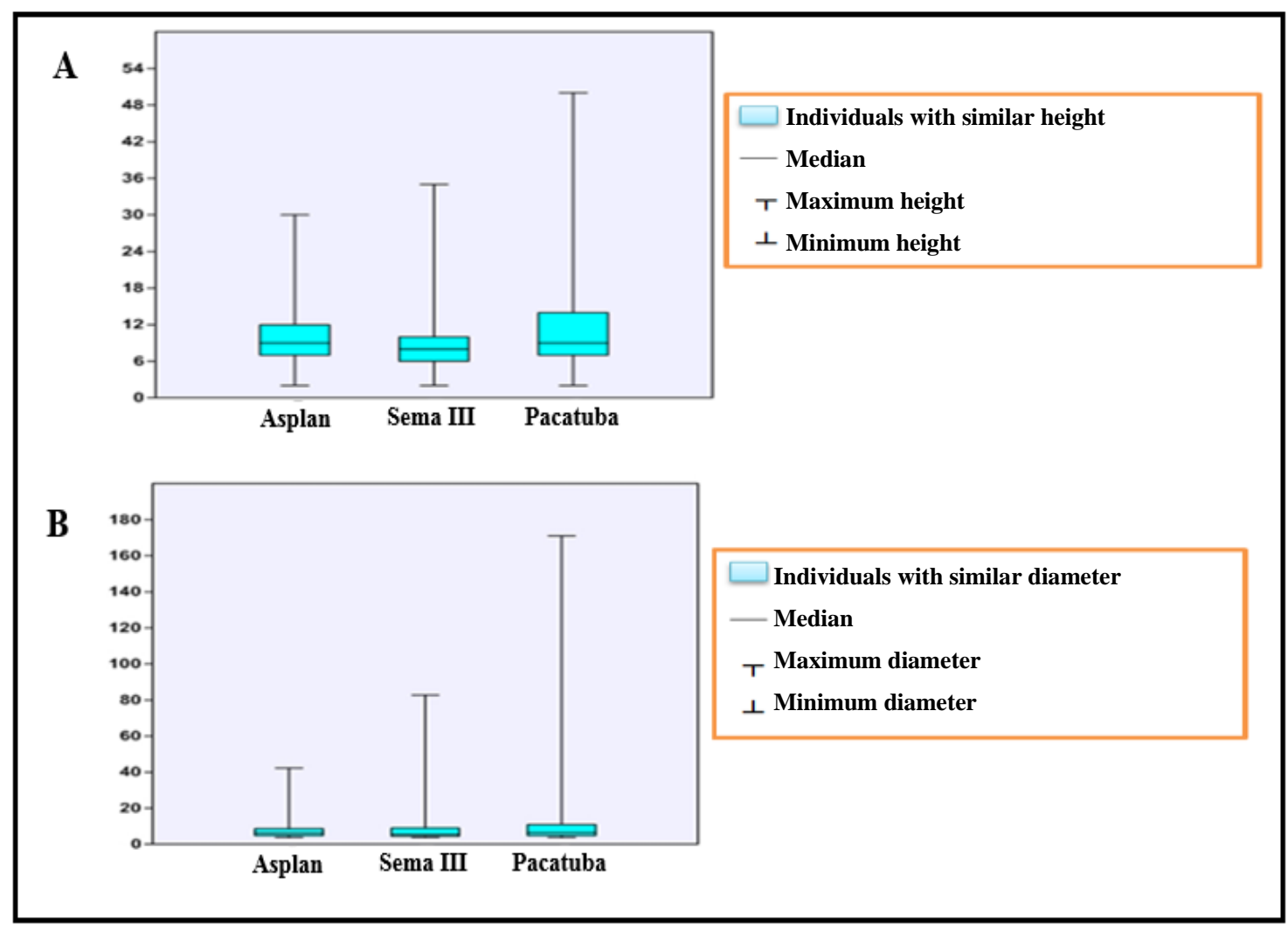

Figure 4. "Box-Plot" graphs of the measurements of trees (in meters) in the three studied areas. A. Differences in height; B. Variations in diameter.

Table 1. Differences in means and standard deviation of height and diameter of trees in the studied forests.

\begin{tabular}{ccccc} 
Study area & \multicolumn{2}{c}{ Height $(\mathbf{m})$} & \multicolumn{2}{c}{ Diameter (cm) } \\
& Mean & Standard Deviation & Mean & Standard Deviation \\
Asplan & 9.91 & \pm 4.05 & 7.97 & \pm 5.25 \\
Pacatuba & 10.5 & \pm 5.6 & 10.34 & \pm 11.8
\end{tabular}



$\pm 6.6$

All diversity indexes indicate Pacatuba Forest as having the highest diversity, while the Asplan Forest had the lowest diversity (Tab. 2).

Table 2. Variation in diversity indexes in the three studied areas.

\begin{tabular}{cccc}
\hline Diversity Index & Pacatuba & Asplan & Sema III \\
\hline Simpson (1-D) & 0.95 & 0.92 & 0.9 \\
Shannon-Wiener (H') & 3.75 & 3.07 & 3.2 \\
Alpha-Fisher & 33.74 & 18.36 & 26.57 \\
\hline
\end{tabular}

Seven species of highest occurrence were indicated for Asplan Forest, four in Pacatuba Forest, and three in REBIO Guaribas Forest (Fig. 5). The most abundant species in Pacatuba Forest was Protium giganteum, while the species Protium heptaphyllum was most frequent in REBIO Guaribas Forest. In Asplan Forest, Eschweilera ovata was the species of highest occurrence. 


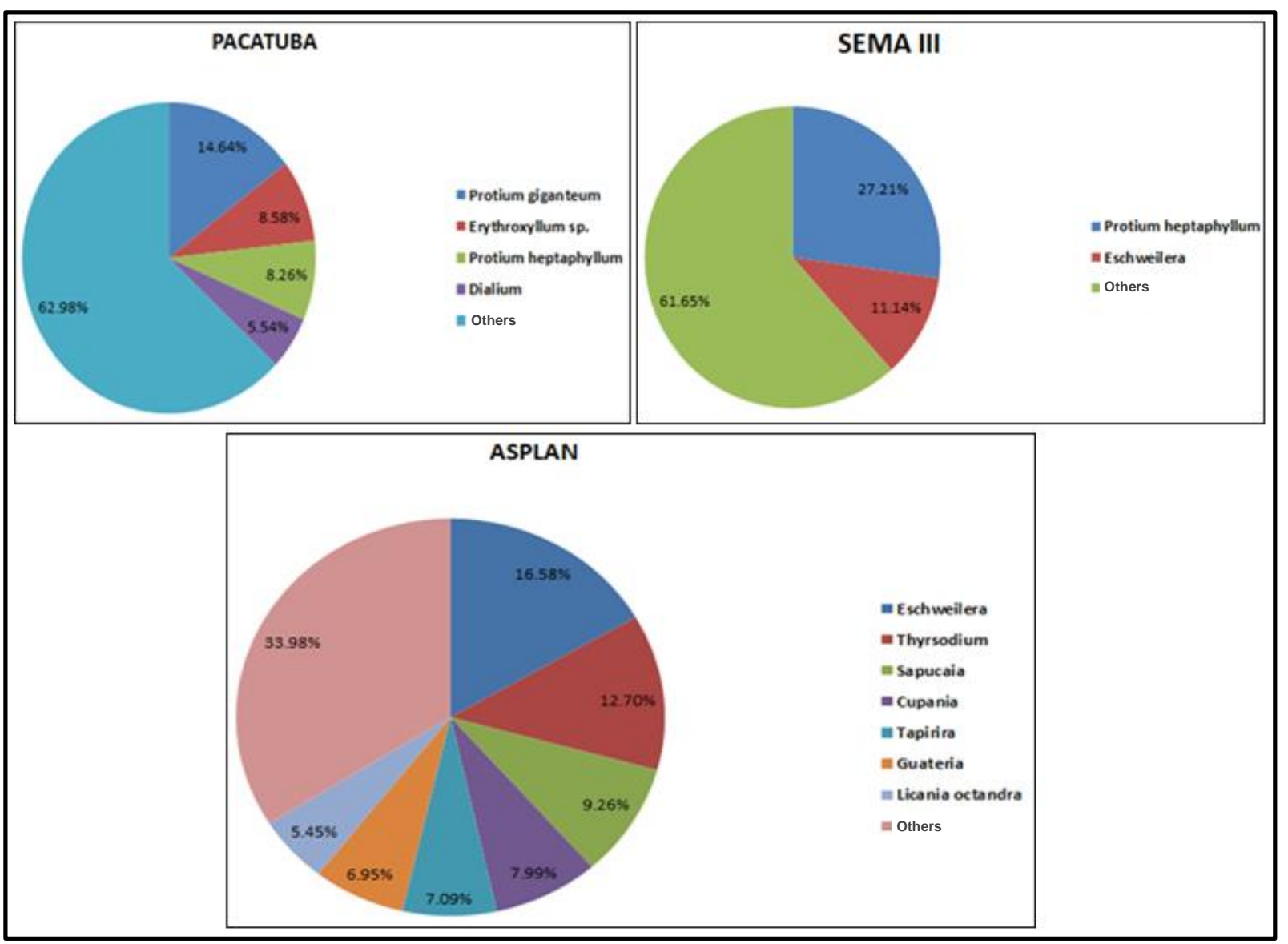

Figure 5. Species with highest abundance in individuals in the sampled areas.

The collector curve, or cumulative species curve, indicates a gradual increase in the number of species for the Asplan Forest, indicating that further species may be found. On the other hand, the REBIO Guaribas Forest and the Pacatuba Forest show a graph line that is close to stabilization, which theoretically indicates that most species have been sampled. The collector curve may not be the best indicator for the total number of species from a given locality, because even after stabilization there is always the possibility that unsampled species will appear. Thus, the use of estimators permits more precision in the evaluation of total species numbers in the studied areas.

Estimates of species richness are very useful, when different communities are compared, or even when comparing the number of species or individuals per sample. Such measurements permit the estimation of the total number of species present in a community on the basis of the sampled data.

According to the estumators Chao ${ }_{1}$ and Jacknife ${ }_{1}$, the REBIO Guaribas or PassionFruit Forest was possibly subsampled, indicating that a larger sampling effort may possibly increase the number or recorded species (Fig. 6). 


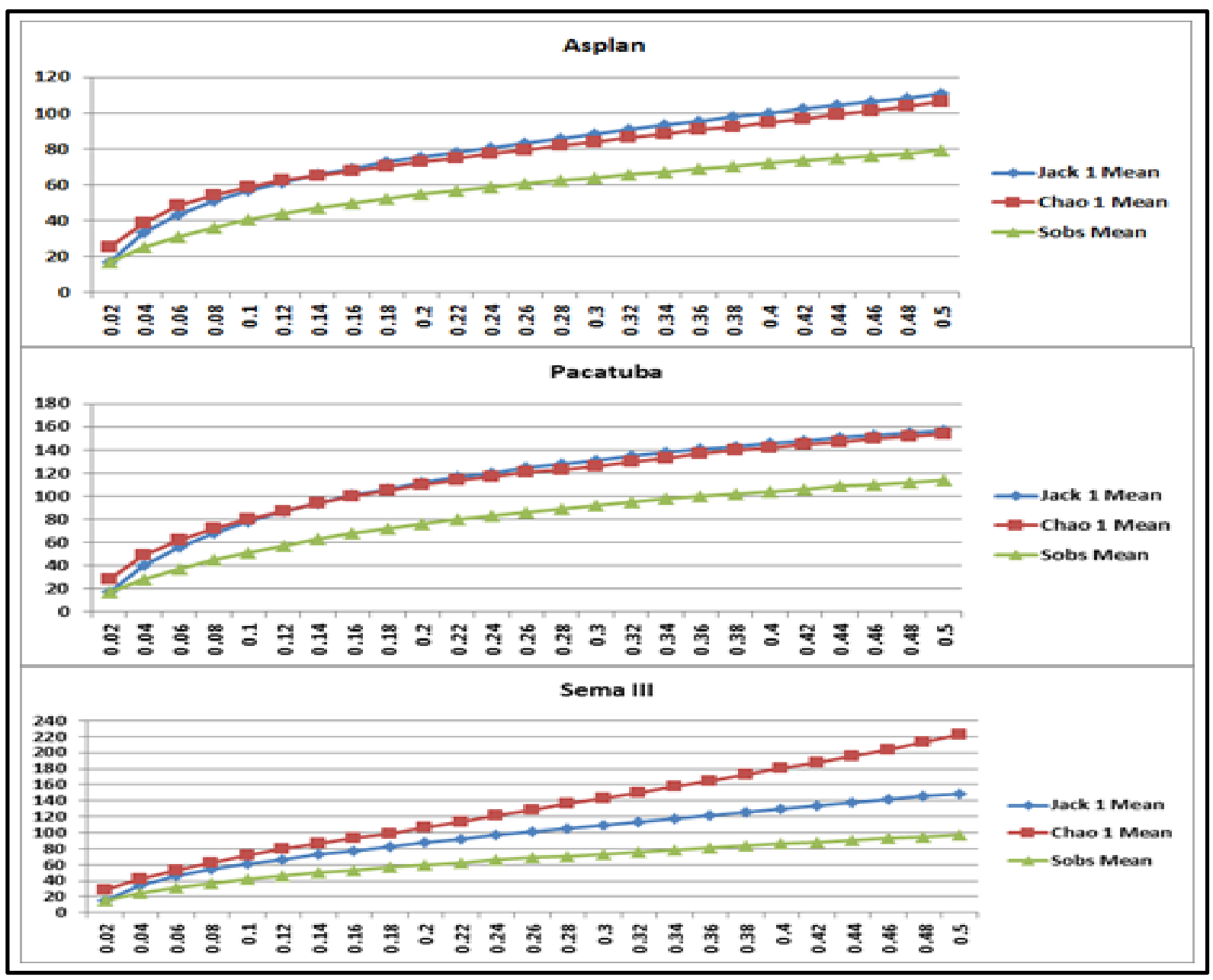

Figure 6. Estimate of the total number of species relative to species effectively sampled.

Pacatuba Forest has a larger number of species of fruit trees consumed by primates ( 31 consumed species). REBIO Guaribas (Sema III) Forest has fewest species consumed by primates (19 species). In Asplan Forest, Tapirira guianensis, a species common in secondary forests or in forests subject to recovery, stands out (e.g. LORENZI, 2002). This species may also be common in fragmented areas, as the Asplan Forest is being subject to stages of regeneration. Other species that have the fruits consumed by primates are: Licania sp., Guatteria sp., and Inga sp. In Pacatuba Forest, the species with fruits eaten by primates were: Ocotea sp., Brosimum sp., Dialium sp., and Garcinia sp. In the REBIO Guaribas Forest the following species were found: Protium spp., Campomanesia sp., Eugenia sp., Guatteria sp., Copaifera sp., Ocotea sp., and Brosimum sp. (Fig. 7).

The species T. guianensis, Licania sp., Guatteria sp. and Inga sp. were the most abundant in the Asplan Forest. Species such as Cecropia sp., Myrcia sp. and Piptadenia were not found in the plots of the Pacatuba Forest, although they occur in the region, having been found in the Asplan Forest (Fig. 7). 
The species that serve as food resources for C. jacchus are: T. guianensis, Inga sp., Cecropia sp., Ocotea sp., Talisia sp., Byrsonima sp., Protium spp., Ficus sp., Brosimum sp., Campomanesia. sp., Eugenia sp., Sorocea sp. and Coccoloba sp. The remaining species, together with some of the previously cited species, serve as a food source for A. belzebul and S. flavius (see Appendix I).

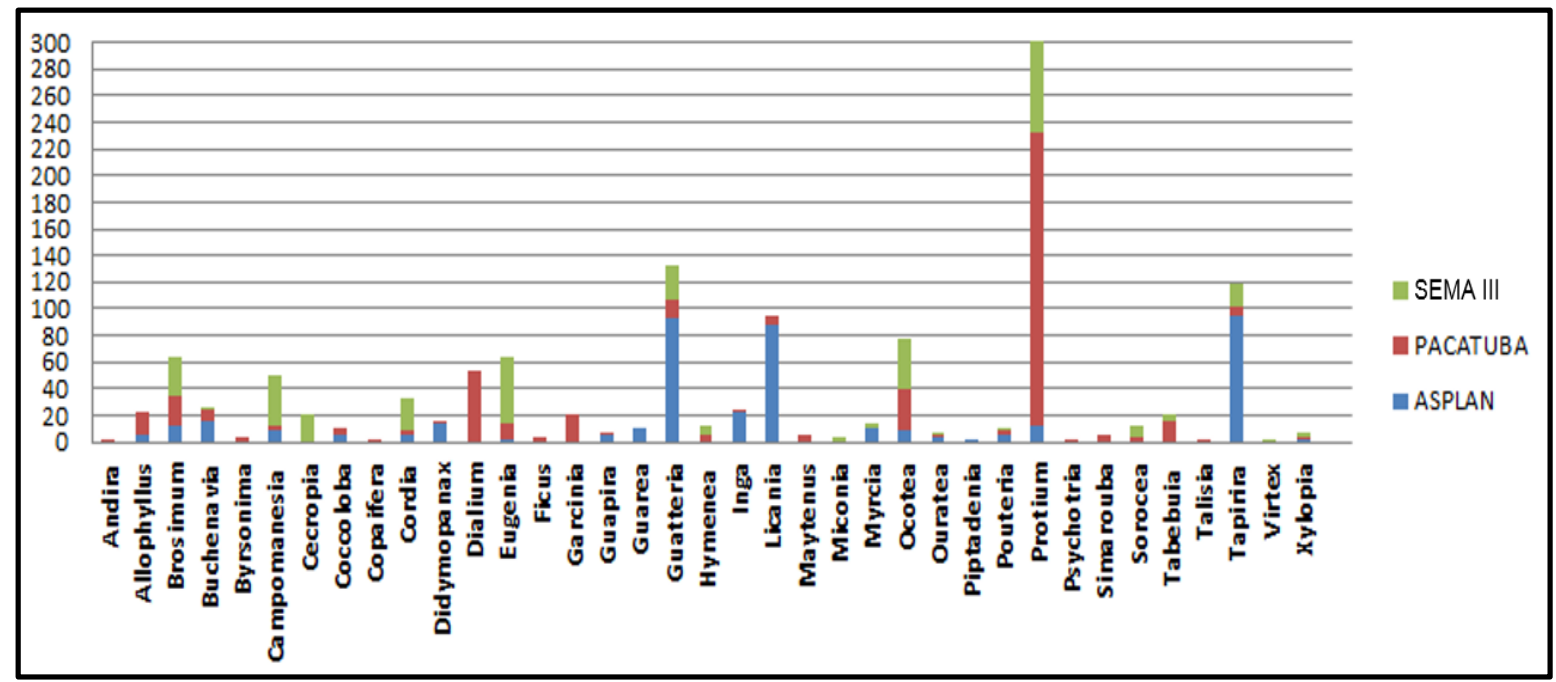

Figure 7. Abundance of trees used as feeding resources by primates in the three studied areas.

In Pacatuba Forest, the species $P$. giganteum, Dialium guianensis and Ocotea sp. were most representative in the studied plots, while the species Brosimum sp., Ocotea sp. and Pouteria sp. were common in the Asplan and Pacatuba Forests. Species belonging to the genera Inga and Tapirira occurred only in the Asplan Forest. On the other hand, the species Garcinia sp. appeared only in the Pacatuba Forest (Fig. 8). During the collection of data in the Asplan Forest, the primate species $S$. flavius was seen very briefly on three occasions, eating a fruit of Inga sp. However, it displayed an agonistic behavior off flight each time it was observed by the researchers.

In the REBIO Guaribas (Sema III) Passion-Fruit Forest, species Ocotea sp. and Brosimum sp. were quite representative in number of individuals, occurring in over $22 \%$ of the plots $(\mathrm{n}=25$ plots); while in the Pacatuba Forest the species D. guianensis occurred in $76 \%$ of the plots. 


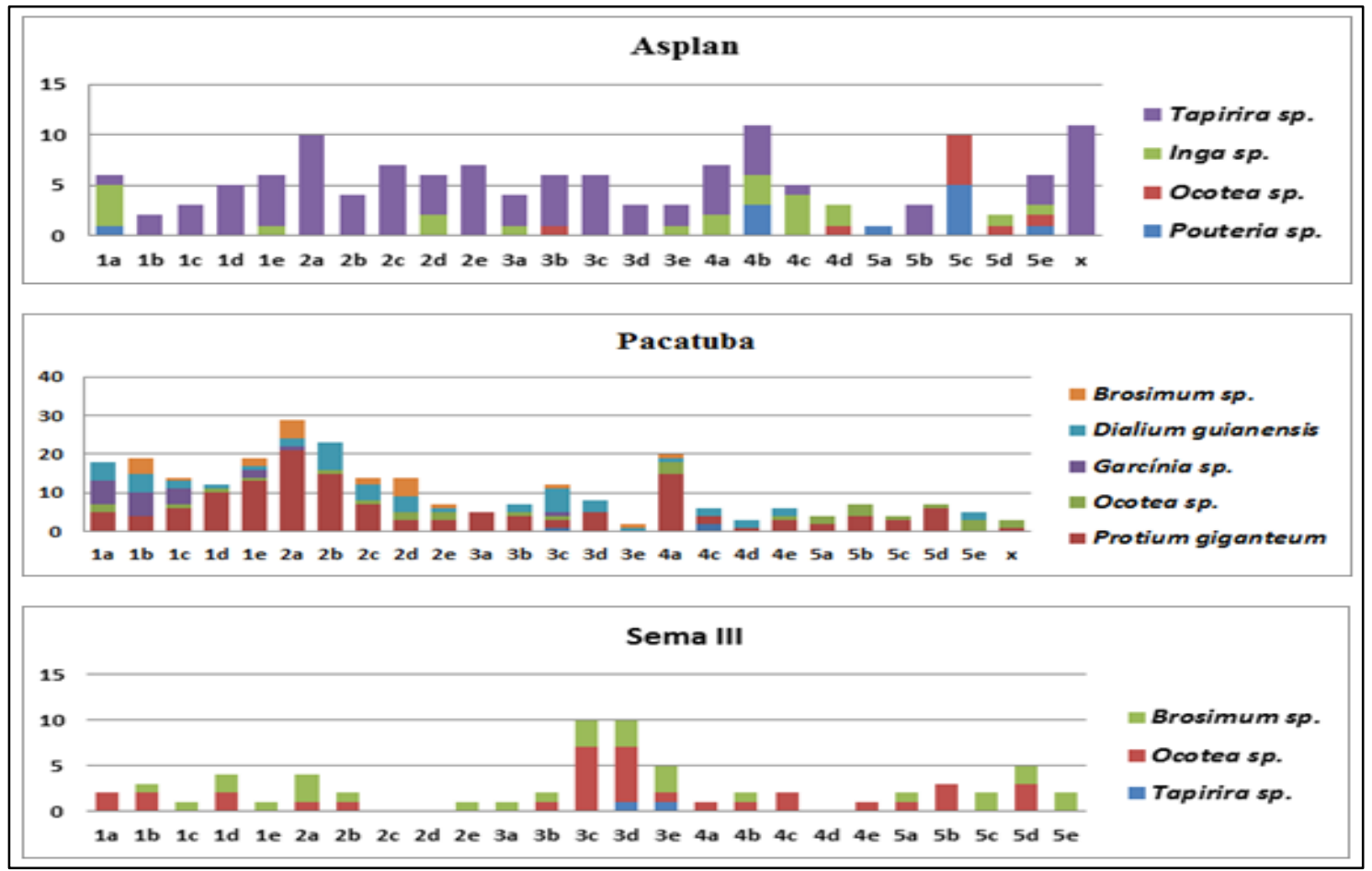

Figure 8. Abundance and distribution of tree species used as food resources (predominantly fruits) by primates in plots in the three areas.

\section{Beta Diversity}

In the Asplan Forest, the mean similarity between plots is much larger. Consequently, Beta diversity is smaller. On the other hand, Pacatuba Forest has least similarity among areas, and consequently presents a higher Beta diversity (Fig. 9).

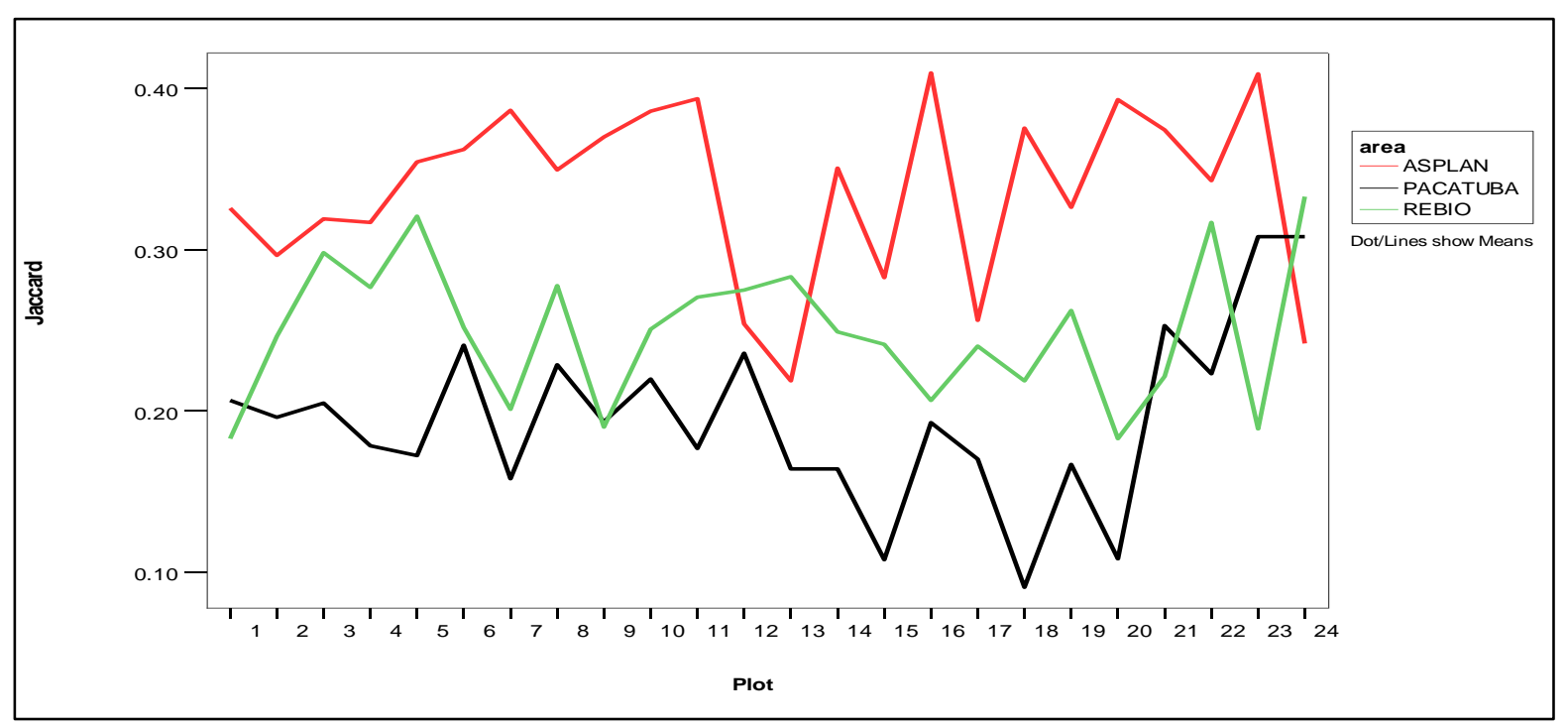

Figure 9. Mean similarity among plots in the studied areas. 
Pacatuba is the forest with the largest number of plant species, that serve as food resources for the primates and also represents the forest with the highest quantity of large seeds and fruits (see Appendices I and II; Fig. 10). Pacatuba and REBIO Guaribas (Sema III) have the largest Beta diversity, while Asplan Forest has the highest similarity, and consequently the smallest Beta diversity. The larger Beta diversity in Pacatuba Forest is possibly due to the heterogeneity of the environment.

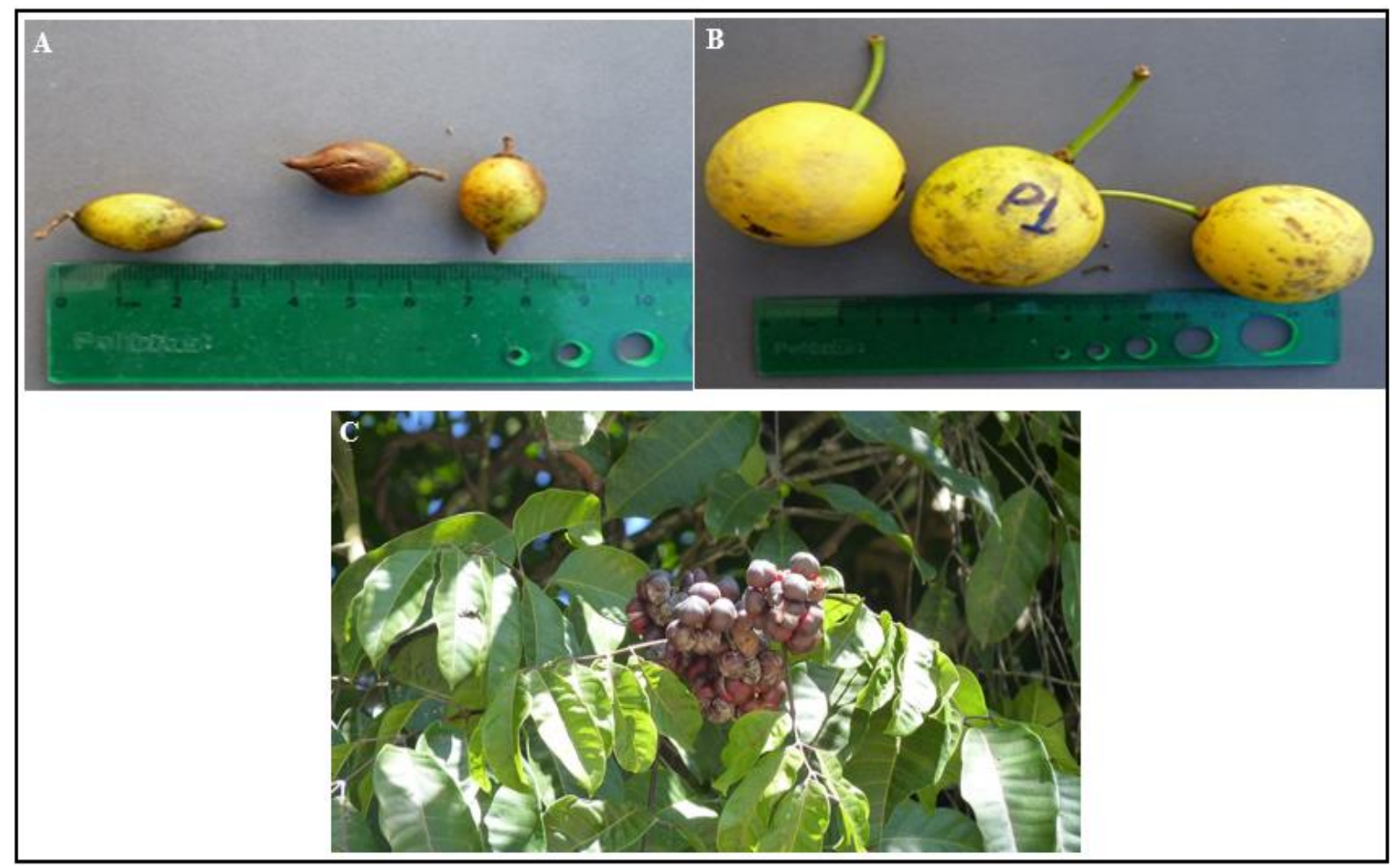

Figure 10. Some fruit consumed by primates in the present research. A. Pouteria sp.; B. Garcinia sp.; C. Protium giganteum. Photos: Antônio Moura, 2013.

The differences in the structure and diversity among the three studied areas may be explained in the light of the history of each area. According to inhabitants surrounding the Asplan Forest, about 30 years ago, when this area was not yet a legal reserve, several environmental perturbations were provoked with the selective exploration of trees for the construction of taipa houses, and by deforestation and burning of sectors of the forest for the production of charcoal. The deforestated areas were further used to cultivate corn and beans. A similar situation afflicted the REBIO Guaribas (Sema III) Forest, before it became a Biological Reserve, but deforestation was less pronounced here. The Pacatuba Forest, due to its greater distance from urban areas, and due to its belonging to the Japungu Sugar-Plant, presents a better state of preservation. 
De Souza (2005) recorded 56 species consumed by primates in the Pacatuba Forest, while we found 31 fruit trees consumed by primates in this same area. Our results are similar to the 34 fruit trees recorded by Bonvicino (1989). The larger number indicated in De Souza (2005) is due to the inclusion of liana plants and arboreal trees, whose leaves and sprouts are also consumed by primates, and to the inclusion of exotic fruit trees, such as Mangifera indica. Tabarelli et al. (2010) state that the forest fragmentation leads to profound changes in the structure of the forest, affecting the morphology and phenology of the plant species. Fragmentation favours the appearance of species with small seeds and fruits, whose proliferation is more efficient. This results in the increase of species with small seeds or with seeds disopersed by wind. In the long run, species with delayed growth and with larger fruits and seeds become replaced by the smaller-seed pioneer species. These results indicate that large primates such as the guariba monkeys (A. belzebul) in the Pacatuba Forest contribute to the dispersal of the larger seeds (> $10.0 \mathrm{~mm}$ ), such as the plant species $P$. giganteum $(11.8$ $\mathrm{mm})$ and Buchenavia grandis $(12.0 \mathrm{~mm})$ (SOUSA, 2013). Perhaps the presence of these animals are in part responsible for the greater diversity found in Pacatuba Forest, for the presence of large-seed species, and for the more homogeneous distribution of these species within the sampled plots. Frugiverous animals disperse seeds of several species, exerting a key role in the regeneration of forested areas. Primates may spit, regurgitate, defecate or simply carry fruits away from the mother-plant, enhancing the probability of survival and germination of seeds (GALETTI; ALVES-COSTA; CAZETTA, 2003; SOUSA, 2013).

In the Asplan Forest we found the primates S. flavius and $C$. jacchus. In the Pacatuba Forest, we found $A$. belzebul and $C$. jacchus. In the REBIO Guaribas Forest only a single species was found $(C$. jacchus). It is probable that the difference in body size among these primates determines the potential for ingestion of seeds of different sizes (IZAR, 2008; LUCAS; CORLETT, 1998; UNGAR, 1995), thus affecting the structure of the forests. For example, D. guianensis occurs only in the Pacatuba Forest and apparently represents the only seed dispersant within this forested area.

The REBIO Guaribas (Sema III) Passion-Fruit Forest does not have primates of medium or large size, such as S. flavius and A. belzebul, and has the smallest number of plant species consumed by primates. It is also possible that the proximity of this area to urban settlements has negatively affected the diversity of species, as a result of its history of perturbation. Furthermore, the low declivity of this area does not favour the formation of microhabitats, resulting in an environment of low heterogeneity. The Asplan Forest had three plant species in addition to those found in the REBIO Guaribas Forest. Perhaps the presence 
of the primate $S$. flavius is reponsible for the permanence of these species, through the dispersion of its seeds. One example of this is the genus Inga, consumed and apparently dispersed by S. flavius, which was found relatively frequently in the Asplan Forest, while in the REBIO Guaribas (Sema III) Forest, not a single individual of the genus Inga was found.

The pioneer plant species T. guianensis is dominant in the Asplan Forest. This species ie relatively common in fragmented areas, indicating that this forested area is in a stage of regeneration. In the Pacatuba Forest, the species D. guianensis presents a large number of individuals, while in the Asplan and REBIO Guaribas Forests, in which there are no guariba monkeys, the seeds have a mean size of $9 \mathrm{~mm}$, which is close to the mean of large-seed species $(10 \mathrm{~mm})$. This correlates strongly with the presence of the primate A. belzebul, apparently the main dispersant of this plant, accounting for its abundance. On the other hand, the species $P$. heptaphyllum is more abundant in the REBIO Guaribas Forest, due to the great annual production of viable seeds by this species, which are dispersed by birds of several species, that appreciate the soft tissue surrounding these seeds (GUARIM NETO, 1991; LIMA, 2012).

In the three studied areas the primates (C. jacchus, A. belzebul and S. flavius), apparently influenced the distribution of species in all or most plots. Of the species consumed by primates, $T$. guianensis, $P$. giganteum and $P$. heptaphyllum are the most common species in Asplan, Pacatuba and Sema III Forests, respectively. The environmental relief of the Pacatuba Forest may also have influenced the higher diversity, due to the presence of more microhabitats in the region. Environments with a constant supply of water guarantee the presence of species that strive in more humid habitats. The occurrence of rare or uncommon species, such as Hamelia patens, Rauia resinosa, and Sarcaulus brasiliensis in the Pacatuba Forest (DIONÍSIO, 2002) is a consequence of the availability of humid environments. Furthermore, in these environments with a larger water availability the forest becomes higher and the vegetation becomes more dense. Although the REBIO Passion-Fruit Forest also has a stream, the primate A. belzebul does not occur there. This primate species is responsible for the dispersion of large-seed plants. Its absence may result, in the long run, in the disappearance of large-seed species, and in the reduction of the oversall plant diversity in the area.

\section{CONCLUSIONS}

Pacatuba is the forest area with the highest availability of food resoruces for primates. It is also the forest with most species of large seeds and fruits. The Pacatuba and REBIO Guaribas 
(Sema III) Forests present the largest Beta diversity. The history of anthropic perturbations may explain the pattern of species richness observed between these two areas. The presence of large-body seed dispersants may have had an important influence on the diversity of tree species observed in the Pacatuba Forest.

\section{ACKNOWLEDGMENTS}

The authors thank the Universidade Federal da Paraíba (Campus IV, Rio Tinto) for the space provided in the Animal Ecology Lab, under the supervision of Prof. Dr. Frederico Gustavo Rodrigues França. We also thank UFPB (Campus I) for the use of the Lauro Pires Xavier Herbarium, where exicata of the collected plant species were deposited. V.S. acknowledges the PIBIC (Programa Institucional de Bolsas de Iniciação Científica) grant received from CNPQ (Conselho Nacional de Desenvolvimento Científico e Tecnológico), during the course "Ecologia"/UFPB. We thank the diretor and employees of the Asplan ("Associação de Plantadores de Cana da Paraíba") Forest, of the sugar plant Japungu (RPPN Pacatuba Farm) and of the Biological Reserve (REBIO) Guaribas/SEMA III, for providing space for the development of the presente research. Special thanks are due to Prof. Dr. Antônio Christian de Andrade Moura for the identification of the plant species and of the primate species present in the study areas. D.A.C acknowledges the Ph.D. grant received from "Fundação de Apoio à Pesquisa do Estado da Paraíba" (FAPESQ), in partnership with Coordenação de Aperfeiçoamento de Pessoal de Nível Superior (CAPES). M.L.C. acknowledges the productivity shcolarship provided by CNPq (Process 302388/2014-1).

\section{REFERENCES}

BARROS, R.S.M. Medidas de diversidade biológica. Trabalho apresentado como parte dos requisitos da disciplina Estágio Docência, Programa de Pós-Graduação em Ecologia Aplicada ao Manejo e Conservação de Recursos Naturais, Universidade Federal de Juiz de Fora, Juiz de Fora, 2007.

BONVICINO, C.R. Ecologia e comportamento de Alouatta belzebul (Primates: Cebidae) na Mata Atlântica. Revista Nordestina de Biologia, João Pessoa, v. 6, n. 2, p. 149-179, 1989.

CAMARGO, C.C.; PORFÍRIO, S.; RYLANDS, A.B.; LANGGUTH, A. Variação sazonal e longitudinal nos padrões de comportamento em uma população de Alouatta belzebul (Primates: Atelidae) do Nordeste Brasileiro. In: FERRARI, S.F.; RÍMOLI, J. (Org.). A 
Primatologia no Brasil. Aracaju: Sociedade Brasileira de Primatologia, 2008. v. 9, p. 192201.

CERQUEIRA, R.; BRANT, A.; NASCIMENTO, M.T.; PARDINI, R. Fragmentação: alguns conceitos. In: RAMBALDI, D. M.; OLIVEIRA, D.A.S (Org.). Fragmentação de ecossistemas: causas, efeitos sobre a biodiversidade e recomendações de políticas públicas. Brasília: Ministério do Meio Ambiente, 2003. p. 23-40.

CHIARELLO, A.G. Diet of the brown howler monkey Alouatta fusca in a semi-deciduous forest fragment of southeastern Brazil. Primates, Quioto, v. 35, n. 1, p. 25-34, 1994.

DALPONTE, J.C.; LIMA, E.S. Disponibilidade de frutos e a dieta de Lycalopex vetulus (Carnivora - Canidae) em um cerrado de Mato Grosso, Brasil. Brazilian Journal of Botany, São Paulo, v. 22, n. 2, p. 325-332, 1999.

DE SOUZA, S.P. Ecologia e conservação de Alouatta belzebul belzebul (Primates, Atelidae) na Paraíba, Brasil. 121 f. Tese (Doutorado em Ecologia, Conservação e Manejo de Vida Silvestre)-Universidade Federal de Minas Gerais, Belo Horizonte, 2005.

DIONÍSIO, G.O. Florística e fitossociologia do estrato arbóreo e arbustivo na Reserva Particular do Patrimônio Natural Fazenda Pacatuba, Sapé - PB. 52 p. Monografia (Bacharelado em Ciências Biológicas)-Universidade Federal da Paraíba, João Pessoa, 2002.

GAlETTI, M.; ALVES-COSTA, C.P.; CAZETTA, E. Effects of forest fragmentation, anthropogenic edges and fruit colour on the consumption of ornithocoric fruits. Biological Conservation, v. 111, n. 2, p. 269-273, 2003.

GILBERT, K.A.; SETZ, E.Z.F. Primates in a fragmented landscape: six species in central Amazonia. In: BIERREGAARD, R.O.; GASCON, C.; LOVEJOY, T.E.; MESQUITA, R. (Org.). Lessons from Amazonia: ecology and conservation of a fragmented forest. New Haven: Yale University Press, 2001. p. 262-270.

GOOGLE EARTH. 2018. Disponível em: 〈http://www.google earth.com.br/>. Acesso em: 15 jun. 2018. 
GUARIM NETO, G. Plantas do Brasil - Angiospermas do Estado de Mato Grosso Pantanal. Acta Botânica Brasílica, v. 5, n. 1, p. 25-47, 1991.

GUREVITCH, J.; SCHEINER, S.M.; FOX, G.A. Ecologia vegetal. 2. ed. Porto Alegre: Artmed, 2009.

KÖPPEN, W. Climatologia: con un estudio de los climas de la tierra. Pánuco: Fondo de Cultura Económica, 1948.

IZAR, P. Dispersão de sementes por Cebus nigritus e Brachyteles arachnoides em área de Mata Atlântica, Parque Estadual Intervales, SP. In: FERRARI, S.F.; RÍMOLI, J. (Org.). A Primatologia no Brasil. Aracaju: Sociedade Brasileira de Primatologia, 2008. v. 9, p. 8-24.

LAURANCE, W.F.; VASCONCELOS, H.L. Conseqüências ecológicas da fragmentação florestal na Amazônia. Oecologia Brasiliensis, Rio de Janeiro, v. 13, n. 3, p. 434-451, 2009.

LIMA, S.C.S. Propagação vegetativa do Protium spp: Protium heptaphyllum, Protium spruceanum e Protium guacayanum. 89 f. Dissertação (Mestrado em Biotecnologia e Recursos Naturais)-Universidade do Estado do Amazonas, Manaus, 2012.

LORENZI, H. Árvores brasileiras: manual de identificação e cultivo de plantas arbóreas do Brasil. Nova Odessa: Instituto Plantarum, 2002. v. 1.

LUCAS, P.W.; CORLETT, R.T. Seed dispersal by long-tailed macaques. American Journal of Primatology, v. 45, n. 1, p. 29-44, 1998.

MOURA, A.C.A.; McCONKEY, K.R. The capuchin, the howler, and the Caatinga: seed dispersal by monkeys in a threatened Brazilian forest. American Journal of Primatology, v. 69, n. 2, p. 220-226, 2007.

PUIG, H. A floresta tropical úmida. São Paulo: Unesp, 2008.

SOUSA, L.L. Alimentação e identificação de sementes dispersadas pelo Alouatta belzebul (Primates, Atelidae) em um fragmento de floresta atlântica na Paraíba, Brasil. 30 f. 
Trabalho de Conclusão de Curso (Bacharelado em Ecologia)-Universidade Federal da Paraíba, Rio Tinto, 2013.

TABARELli, M.; AGUIAR, A.V.; GIRÃO, L.C.; PERES, C.A.; LOPES, A.V. Effects of pioneer tree species hyperabundance on forest fragments in Northeastern Brazil. Conservation Biology, v. 24, n. 6, p. 1654-1663, 2010.

UNGAR, P.S. Fruit preferences of four sympatric primate species at Ketambe, northern Sumatra, Indonesia. International Journal of Primatology, v. 16, n. 2, p. 221-245, 1995.

\section{APPENDIX I}

List of arboreal genera the fruit of which are consumed by the primates Callithrix jacchus $(\mathrm{j})$, Sapajus flavius ( f ) and Alouatta belzebul ( b )

\begin{tabular}{|c|c|c|c|c|}
\hline Species & Asplan & Pacatuba & Sema III & Fruits \\
\hline Andira & & $X$ & & $\mathrm{~b}$ \\
\hline Allophyllus & $X$ & $X$ & & $\mathrm{~b}$ \\
\hline Brosimum & $X$ & $X$ & $\mathrm{X}$ & $j f b$ \\
\hline Buchenavia & $X$ & $X$ & $X$ & $\mathrm{~b}$ \\
\hline Byrsonima & & $\mathrm{X}$ & & $\mathrm{jb}$ \\
\hline Campomanesia & $X$ & $X$ & $X$ & $\mathrm{j} b$ \\
\hline Cecropia & $X$ & & $X$ & $\mathrm{~b}$ \\
\hline Coccoloba & $\mathrm{X}$ & $X$ & & $\mathrm{j} \mathrm{b}$ \\
\hline Copaifera & & $X$ & & $\mathrm{f}$ \\
\hline Cordia & $X$ & $X$ & $\mathrm{X}$ & $\mathrm{b}$ \\
\hline Didymopanax & $X$ & $\mathrm{X}$ & & $\mathrm{b}$ \\
\hline Eugenia & $X$ & $X$ & $X$ & $\mathrm{j} b$ \\
\hline Dialium & & $X$ & & $\mathrm{~b}$ \\
\hline Ficus & & $X$ & & $\mathrm{j} f \mathrm{~b}$ \\
\hline Garcinia & & $\mathrm{X}$ & & $\mathrm{b}$ \\
\hline Guapira & $\mathrm{X}$ & $\mathrm{X}$ & & $\mathrm{jfb}$ \\
\hline Guarea & $X$ & & & $\mathrm{fb}$ \\
\hline Guatteria & $X$ & $X$ & $X$ & $\mathrm{~b}$ \\
\hline Hymenea & & $\mathrm{X}$ & $X$ & $\mathrm{f}$ \\
\hline Inga & $\mathrm{X}$ & $\mathrm{X}$ & $X$ & $\mathrm{jfb}$ \\
\hline Licania & $X$ & $X$ & $X$ & $\mathrm{fb}$ \\
\hline Maytenus & & $X$ & $X$ & $\mathrm{~b}$ \\
\hline Miconia & & & $X$ & $\mathrm{fb}$ \\
\hline Myrcia & $\mathrm{X}$ & & $X$ & $\mathrm{~b}$ \\
\hline
\end{tabular}




\begin{tabular}{ccccc} 
Ocotea & $\mathrm{X}$ & $\mathrm{X}$ & $\mathrm{X}$ & $\mathrm{j} \mathrm{b}$ \\
Ouratea & $\mathrm{X}$ & $\mathrm{X}$ & $\mathrm{X}$ & $\mathrm{b}$ \\
Piptadenia & $\mathrm{X}$ & & $\mathrm{X}$ & $\mathrm{b}$ \\
Pouteria & $\mathrm{X}$ & $\mathrm{X}$ & $\mathrm{X}$ & $\mathrm{b}$ \\
Protium & $\mathrm{X}$ & $\mathrm{X}$ & $\mathrm{X}$ & $\mathrm{j} \mathrm{b}$ \\
Psychotria & & $\mathrm{X}$ & $\mathrm{X}$ & $\mathrm{b}$ \\
Simarouba & & $\mathrm{X}$ & $\mathrm{X}$ & $\mathrm{b}$ \\
Sorocea & & $\mathrm{X}$ & $\mathrm{X}$ & $\mathrm{j} \mathrm{f} \mathrm{b}$ \\
Tabebuia & & $\mathrm{X}$ & $\mathrm{b}$ \\
Talesia & & $\mathrm{X}$ & $\mathrm{X}$ & $\mathrm{j} \mathrm{b}$ \\
Tapirira & $\mathrm{X}$ & $\mathrm{X}$ & $\mathrm{j} \mathrm{f} \mathrm{b}$ \\
Virtex & & $\mathrm{X}$ & $\mathrm{X}$ & $\mathrm{b}$ \\
Xylopia & $\mathrm{X}$ & $\mathrm{X}$ & $\mathrm{b}$ \\
\hline
\end{tabular}

\section{APPENDIX II}

List of arboreal genera with medium- and large-sized seeds (* seeds with median size $\geq 5 \mathrm{~mm}$ and $\leq 10 \mathrm{~mm}, * *$ large seeds $>10 \mathrm{~mm}$ )

\begin{tabular}{|c|c|c|}
\hline Asplan & Pacatuba & Sema III \\
\hline Buchenavia ** & Buchenavia ** & Buchenavia ** \\
\hline Campomanesia* & Byrsonima * & Campomanesia * \\
\hline Eugenia* & Campomanesia* & Eugenia* \\
\hline $\operatorname{Ing} a * *$ & Copaifera $* *$ & Hymenea ** \\
\hline \multirow[t]{6}{*}{ Protium $* *$} & Dialium * & Protium ** \\
\hline & Eugenia* & \\
\hline & Hymenea ** & \\
\hline & Inga** & \\
\hline & Maytenus * & \\
\hline & Protium ** & \\
\hline
\end{tabular}

